\title{
EFEKTIFITAS EDUKASI KADER KESEHATAN TERHADAP PENINGKATAN PENGETAHUAN DAN KEMAMPUAN MENDETEKSI DINI TANDA BAHAYA PADA KEHAMILAN DAN NIFAS TAHUN 2016
}

\author{
Diyah Sri Yuhandini ${ }^{1}$, Santi Wahyuni ${ }^{2}$, Neli Nurlina ${ }^{3}$ \\ Program Studi Sarjana Terapan Kebidanan, Jurusan Kebidanan, Poltekkes Kemenkes Tasikmalaya \\ e-mail: ${ }^{1}$ diyahsriyuhandini80@gmail.com, ${ }^{2}$ daffa_keisha@yahoo.com, ${ }^{3}$ nelinurlina2014@gmail.com
}

\begin{abstract}
Background: The volunteer is the elements society who tasked with developing society and as health promoters. Data Puskesmas Sitopeng 2015, high risk detection by health workers was 161.67\%, high risk detection by the community was $62.37 \%$. The data illustrates the early detection of high-risk pregnancy by people still below the government's target (80\%). Objective: Determine the effectiveness of education for health volunteers to improve knowledge and ability to detect early danger signs in pregnancy and postpartum in Sitopeng Health Center of Cirebon, 2016. Methods: Quasi-experiment research with one group pretest-posttest. Subjects 24 health volunteers. Analysis data used univariable and bivariable with Wilcoxon test, 95\% CI with a significance level of $p$ <0.05. Results: The mean of knowledge before education was 15.58 while after education amounted to 17.2. The mean capacity for early detection before the education of 13.33 while after education was 21.25. Differences in knowledge before and after education was with a p-value of $>0.05$ (0.081) and the difference of the early detection was with a p-value of $<0.05$ (0.014). Conclusion: There was no significant correlation between knowledge and there was a significant correlation between ability to detect early danger signs in pregnancy and postpartum before and after education for health volunteers.
\end{abstract}

Keywords: Education; Health Volunteers; Knowledge;Early Detection Ability; Danger Signs of Pregnancy and Postpartum.

\begin{abstract}
ABSTRAK
Latar Belakang : Kader merupakan tenaga masyarakat yang bertugas mengembangkan masyarakat dan sebagai promotor kesehatan. Data di Puskesmas Sitopeng tahun 2015 deteksi resiko tinggi oleh tenaga kesehatan sebesar $161,67 \%$, namun deteksi resiko tinggi oleh masyarakat hanya sebesar 62,37\%. Data tersebut menggambarkan deteksi dini kehamilan risiko tinggi oleh masyarakat dibawah target pemerintah (80\%). Tujuan Penelitian: Mengetahui efektifitas edukasi kader kesehatan terhadap peningkatan pengetahuan dan kemampuan mendeteksi dini tanda bahaya pada kehamilan, dan nifas di Wilayah Kerja UPTD Puskesmas Sitopeng Kota Cirebon Tahun 2016. Metode Penelitian: Desain penelitian quasi eksperiment dengan rancangan one group pretest-posttest. Subjek penelitian adalah 24 orang kader kesehatan. Analisis data univariabel dan bivariabel dengan Uji Wilcoxon , 95\% CI dengan tingkat kemaknaan $\mathrm{p}<0,05$. Hasil: Rata-rata pengetahuan sebelum edukasi sebesar 15.58, dan sesudah edukasi sebesar 17.2. Rata-rata kemampuan deteksi dini sebelum edukasi sebesar 13.33 dan sesudah edukasi sebesar 21.25. Perbedaan pengetahuan sebelum dan sesudah $\mathrm{P}>0,05(0,081)$ dan perbedaan kemampuan deteksi dini $\mathrm{P}<0,05$ ( 0,014). Kesimpulan: Tidak terdapat hubungan yang bermakna pada pengetahuan dan ada hubungan yang bermakna pada kemampuan mendeteksi dini tanda bahaya pada kehamilan, dan nifas baik sebelum dan sesudah edukasi kader kesehatan.
\end{abstract}

Kata Kunci : Edukasi; Kader Kesehatan; Pengetahuan; Kemampuan Deteksi Dini; Tanda Bahaya Kehamilan dan Nifas.

\section{PENDAHULUAN}

\section{Latar Belakang}

Menurut Survei Demografi dan Kesehatan Indonesia (SDKI) tahun 2012, angka kematian ibu (AKI) di Indonesia meningkat yaitu 359/100.000 kelahiran hidup. ${ }^{(3)}$ Peningkatannya melebihi AKI tahun 1997 yaitu 334/100.000 kelahiran hidup. Target penurunan AKI tahun 2014 adalah 280/100.000 kelahiran hidup dan target MDGs tahun 2015 adalah 102/100.000 kelahiran hidup. Data tersebut menunjukkan masih tingginya AKI di Indonesia.

AKI di Kota Cirebon pada tahun 2012 adalah 65 kasus dari jumlah kelahiran hidup 47.040, dengan kematian pada ibu hamil 16 kasus (usia < 20 tahun sebanyak 3 kasus, usia 20-34 sebanyak 7 kasus dan usia $\geq 35$ tahun sebanyak 6 kasus), kematian pada ibu bersalin 16 kasus (usia 20-34 14 kasus dan usia $\geq 35$ tahun 2 kasus), kematian pada ibu nifas 33 kasus (usia 
$<20$ tahun sebanyak 2 kasus, usia 20-34 sebanyak 20 kasus dan usia $\geq 35$ tahun sebanyak 11 kasus). AKI Kota Cirebon tahun 2013 sebanyak 3 orang per 5540 Kelahiran Hidup dengan penyebab langsung kematian ibu yang disebabkan oleh eklampsi 2 orang dan penyebab tidak langsung yaitu suspect jantung 1 orang, sedangkan AKI tahun 2014 sebanyak 4 orang per 5483 Kelahiran Hidup dengan penyebab langsung kematian ibu yang disebabkan oleh eklampsi 1 orang dan PEB 1 orang dan perdarahan post partum 2 orang. Dengan meningkatnya kematian hal ini menggambarkan pemeriksaan fisik pada saat antenatal untuk deteksi dini faktor resiko masih belum maksimal. (2)

Berbeda dengan kondisi di Wilayah Kota Cirebon, tahun 2014 Cakupan K1 sebesar $98 \%$ dan Cakupan K4 sebesar 90,50 \% dari target Depkes $95 \%$, terdapat kesenjangan K1 drop out pada kunjungan K4 sebesar 7,5\%. Kunjungan Nifas 3 ( KF 3 ) dari target Depkes tahun 2015 sebesar $90 \%$, di Kota Cirebon cakupan KF 3 tahun 2014 sebesar $87 \%$. Hal ini dikarenakan sebagian masyarakat yang kurang puas dengan kualitas pelayanan petugas dimana bidan merangkap tugas dan melanjutkan pendidikan. Dan khususnya di Puskesmas Sitopeng pada tahun 2014 data cakupan K1 sebesar 100,4 \%, K4 81,5\%. Hal ini berarti pada tahun 2014 masih terdapat 18,9\% ibu hamil yang tidak melakukan kunjungan ulang (K4) ke fasilitas kesehatan. Persalinan di fasilitas kesehatan tahun 2014 sebesar 87,12\%. Persalinan oleh tenaga Kesehatan masih 90,3\% dan masih ada persalinan oleh dukun sebesar 4,41\%. Hal ini dapat disebabkan karena kurang pahamnya masyarakat terhadap pentingnya pemeriksaan kesehatan selama kehamilan, pasca persalinan, dan persalinan oleh tenaga kesehatan. Sehingga perlu adanya dukungan dan partisipasi masyarakat yang secara sukarela berperan aktif dalam penanganan kesehatan secara mandiri.

Penyebab kematian ibu di Indonesia digambarkan dengan trias klasik, yaitu perdarahan, ekplamsia dan infeksi. ${ }^{(5)}$ Kematian ibu dapat dipengaruhi oleh tiga terlambat dan empat terlalu. ${ }^{(1)}$ Faktor tiga terlambat meliputi keterlambatan di tingkat keluarga dalam mengenali tanda-tanda bahaya dan membuat keputusan untuk segera mencari pertolongan, keterlambatan dalam mencapai fasilitas pelayanan kesehatan dan keterlambatan fasilitas pelayanan kesehatan untuk mendapatkan pertolongan yang dibutuhkan. Sedangkan faktor empat terlalu meliputi terlalu muda, terlalu tua, terlalu sering dan terlalu banyak.

Salah satu upaya untuk mencegah keterlambatan tersebut adalah deteksi dini mengenai faktor risiko dan komplikasi kebidanan. ${ }^{(1)}$ Deteksi dini tanda bahaya kehamilan dan nifas sangat diperlukan untuk menemukan ibu hamil dan nifas yang kemungkinan mengalami tanda bahaya atau komplikasi. Pelaksanaan deteksi dini terhadap tanda bahaya kehamilan dan nifas dilakukan dengan pemeriksaan kehamilan atau Antenatal Care (ANC), dan Kunjungan Nifas (KF), pemberian Komunikasi
Informasi dan Edukasi (KIE), pemberian buku Kesehatan Ibu dan Anak (KIA) atau Kartu Menuju Sehat (KMS) ibu hamil. Kegiatan deteksi dini dapat dilakukan oleh tenaga kesehatan dan masyarakat (ibu hamil, tokoh masyarakat dan kader kesehatan) sehingga penanganan yang adekuat dapat segera dilakukan. Hal ini merupakan kunci keberhasilan dalam menurunkan morbiditas dan mortalitas ibu.

Kader merupakan tenaga masyarakat yang keberadaannya berada di barisan terdepan di masyarakat, di pilih masyarakat dan bertugas mengembangkan masyarakat. Sekaligus juga sebagai promotor kesehatan yang bertanggungjawab atas masyarakat setempat. Diharapkan mereka dapat melaksanakan petunjuk yang diberikan oleh para pembimbing dalam jalinan kerjasama dari sebuah tim kesehatan. Dengan terbentuknya kader kesehatan pelayanan kesehatan yang selama ini dikerjakan oleh petugas kesehatan dapat dibantu oleh masyarakat. Dengan adanya kader maka pesan-pesan yang disampaikan dapat diterima dengan sempurna. Kader kesehatan mempunyai peran besar dalam upaya meningkatkan kemampuan masyarakat menolong dirinya untuk mencapai derajat kesehatan yang optimal. Salah satu peran kader kesehatan yang merupakan sumber daya manusia, mereka dapat membantu tenaga kesehatan dalam mendeteksi dini terhadap tanda bahaya kehamilan dan nifas. Tugas kader kesehatan dalam deteksi dini ibu hamil dan nifas dengan faktor risiko adalah mengidentifikasi ibu hamil dan nifas, memberikan penyuluhan selama kehamilan dan nifas, melakukan rujukan ke fasilitas pelayanan kesehatan (puskesmas, rumah sakit) sesuai dengan risiko yang ditemukan. ${ }^{(10)}$

Data dari Puskesmas Sitopeng tahun 2015 bahwa deteksi resiko tinggi oleh tenaga kesehatan sebesar 161,67\%, namun deteksi resiko tinggi oleh masyarakat hanya sebesar $62,37 \%$. Data tersebut menggambarkan deteksi dini kehamilan risiko tinggi oleh masyarakat masih dibawah target pemerintah $(80 \%)$. Berdasarkan hasil wawancara kepada 4 orang ibu kader wilayah Kerja UPTD Puskesmas Sitopeng hampir semuanya belum memahami tentang tandatanda bahaya kehamilan dan tanda-tanda bahaya nifas, walaupun semuanya sudah pernah terpapar informasi tentang hal tersebut namun dalam pelaksanaan perannya di masyarakat untuk mendeteksi tanda bahaya pada kehamilan dan nifas masih belum optimal. Pelaksanaan pendidikan kesehatan di Wilayah Kerja UPTD Puskesmas Sitopeng sendiri juga belum secara rutin dilakukan. Kondisi masyarakat yang terkadang masih harus di jemput bola agar mau memeriksakan kehamilan maupun nifas nya pun masih terjadi. Salah satu contohnya adanya ibu hamil yang usia muda yang tidak mau memeriksakan kehamilannya ke Puskesmas dan pada saat posyandupun untuk memeriksakan kehamilannya terkadang masih harus dijemput oleh kader. Masih adanya persepsi masyarakat yang menganggap Puskesmas hanya sebagai tempat memeriksakan kesehatan yang sudah bermasalah. 
Pada kegiatan pelayanan kesehatan posyandu sendiri juga terkadang masih memanfaatkan rumahrumah kader kesehatan sebagai tempat pelaksanaan kegiatannya. Kader kesehatan memberikan motivasi kepada ibu hamil dan ibu nifas untuk memeriksakan kehamilan dan masa nifasnya. Sedangkan berdasarkan informasi dari bagian Promosi Kesehatan ( PromKes ) UPTD Puskesmas Sitopeng bahwa selama ini informasi / materi yang diberikan oleh petugas bagian Promkes ataupun pada saat pertemuan pewakilan kader di Dinas Kesehatan tentang tanda bahaya pada kehamilan dan nifas disampaikan bersamaan dengan informasi atau materi yang lainnya dan metode yang sering digunakan yaitu dengan metode Ceramah Tanya Jawab, tidak ada juga kegiatan pre dan post test untuk mengevaluasi pengetahuan sebelum dan sesudah diberikan informasi dan belum pernah dilakukan evaluasi kemampuan kader dalam mendeteksi dini tanda bahaya pada kehamilan dan nifas.

Angka kematian Ibu ( AKI ) saat ini masih kita perlu upayakan penurunannya. Kematian ibu dapat dicegah melalui deteksi dini baik ditingkat masyarakat oleh masyarakat ataupun oleh tenaga kesehatan. Penanganan tanda bahaya kehamilan dan nifas secara dini akan menyelamatkan ibu dan bayi dari kematian yang tidak dikehendaki. Peran kader diharapkan dapat membantu dan sekaligus menjadi pilar keluarga dalam upaya mencapai kesejahteraannya.

Berdasarkan uraian di atas, maka peneliti tertarik untuk melakukan penelitian yang berjudul "Efektifitas Edukasi Kader Kesehatan Terhadap Peningkatan Pengetahuan dan Kemampuan Mendeteksi Dini Tanda Bahaya Pada Kehamilan, dan Nifas di Wilayah Kerja UPTD Puskesmas Sitopeng Kota Cirebon Tahun 2016".

\section{Tujuan Penelitian}

Mengetahui efektifitas edukasi kader kesehatan terhadap peningkatan pengetahuan dan kemampuan mendeteksi dini tanda bahaya pada kehamilan, dan nifas di Wilayah Kerja UPTD Puskesmas Sitopeng Kota Cirebon Tahun 2016.

\section{METODE}

Penelitian ini menggunakan desain penelitian quasi eksperimen dengan rancangan one group pretestposttest dengan intervensi edukasi berupa edukasi kader kesehatan tentang pengenalan tanda bahaya pada kehamilan, dan nifas.

Penelitian ini tidak menggunakan kelompok pembanding, namun sudah menggunakan tes awal sehingga besarnya efek atau pengaruh edukasi dapat diketahui secara pasti.

Populasi target adalah seluruh kader kesehatan yang aktif di wilayah kerja UPTD Puskesmas Sitopeng Kota Cirebon Tahun 2016 sebanyak 109 orang. Sampel penelitian menggunakan purposive sampling yaitu Kader Kesehatan yang statusnya aktif di dua RW yang memiliki ibu hamil atau ibu nifas terbanyak dengan resiko tinggi di Wilayah Kerja UPTD Puskesmas Sitopeng Kota Cirebon,yaitu RW 8 dan RW 9, dengan kriteria inklusi yaitu kader yang dapat membaca dan menulis, dan bersedia menjadi responden dan hadir pada pertemuan selama proses penelitian (pengambilan data / pre dan post edukasi dan pada saat edukasi). Jumlah sampel dalam penelitian ini berjumlah 24 orang kader kesehatan.

Penelitian ini akan dilaksanakan di Wilayah Kerja UPTD Puskesmas Sitopeng Kota Cirebon. Tempat pengambilan data di kumpulkan di Puskesmas / Baperkam RW 2. Waktu pelaksanaan penelitian ini dialokasikan dalam rentang waktu satu tahun yaitu periode tahun 2016.

Dalam penelitian ini, subjek penelitian terlebih dahulu diberikan tes awal (pretest) untuk mengetahui sejauh mana pengetahuan dan kemampuan kader dalam mendeteksi tanda bahaya pada kehamilan, dan nifas, dilakukan secara langsung pada ibu hamil dan ibu nifas. Selanjutnya subjek diberikan perlakuan yaitu edukasi tentang tanda bahaya kehamilan, dan nifas. Setelah selesai edukasi, pada pertemuan selanjutnya subjek penelitian diberikan tes akhir (posttest) untuk mengetahui sejauhmana efektifitas edukasi terhadap peningkatan pengetahuan dan kemampuan kader dalam mendeteksi tanda bahaya kehamilan, dan nifas langsung pada ibu hamil dan ibu nifas.

\section{HASIL}

Responden penelitian ini adalah 24 orang ibu kader yang berasal dari daerah RW 8 dan RW 9 Kelurahan Argasunya Kecamatan Sitopeng Kota Cirebon.

1. Analisis Univariat a. Usia

Tabel 1. Distribusi responden berdasarkan usia

\begin{tabular}{|l|c|c|}
\hline \multicolumn{1}{|c|}{ Usia } & $\begin{array}{c}\text { Frekuensi } \\
\text { (n) }\end{array}$ & Persentase (\%) \\
\hline$<20$ tahun & 2 & 8,33 \\
\hline $20-35$ tahun & 14 & 58,3 \\
\hline$>35$ tahun & 8 & 33,33 \\
\hline Total & 24 & 100 \\
\hline
\end{tabular}

Berdasarkan tabel 1, diketahui bahwa responden penelitian ini mayoritas berusia pada kelompok 20-35 tahun, yaitu 58,3\%

\section{b. Pendidikan}

Tabel 2. Distribusi frekeunsi responden berdasarkan pendidikan 
Vol. 16 No. 1 Januari - April 2021

\begin{tabular}{|c|c|c|}
\hline Pendidikan & $\begin{array}{c}\text { Frekuensi } \\
\text { (n) }\end{array}$ & $\begin{array}{c}\text { Persentase } \\
\text { (\%) }\end{array}$ \\
\hline Tidak tamat SD & 2 & 8,3 \\
\hline SD & 15 & 62,5 \\
\hline SMP & 5 & 20,8 \\
\hline SMA & 1 & 4,2 \\
\hline PT & 1 & 4,2 \\
\hline TOTAL & 24 & 100 \\
\hline
\end{tabular}

Berdasarkan table 2, diketahui bahwa mayoritas responden penelitian ini berlatarbelakang pendidikan SD $(62,5 \%)$, hanya satu responden $(4,2 \%)$ yang mencapai pendidikan perguruan tinggi (S1). Dua responden $(8,3 \%)$ diantaranya tidak mengikuti pendidikan formal (SD) dan ada yang tidak tamat SD.

\section{c. Pekerjaan}

Tabel 3. Distribusi frekuensi responden berdasarkan pekerjaan
Tabel 5. Rata-rata Kemampuan Deteksi Dini Kader Kesehatan Tentang Tanda Bahaya Kehamilan dan Nifas Sebelum dan Sesudah Edukasi

\begin{tabular}{|l|l|c|c|c|}
\hline \multirow{2}{*}{ No } & \multirow{2}{*}{ Edukasi } & \multicolumn{3}{|c|}{$\begin{array}{c}\text { Kemampuan Deteksi Dini } \\
\text { Tanda Bahaya Kehamilan } \\
\text { dan Nifas }\end{array}$} \\
\cline { 3 - 5 } & & $\mathrm{N}$ & $\dot{\mathrm{x}}($ Mean $)$ & $\mathrm{SD}$ \\
\hline 1 & Sebelum Edukasi & 24 & 13.33 & 7.020 \\
2 & Setelah Edukasi & 24 & 21.25 & $\begin{array}{c}11.53 \\
9\end{array}$ \\
\hline
\end{tabular}

Berdasarkan tabel 5, kemampuan kader kesehatan dalam deteksi dini tanda bahaya kehamilan dan nifas sebelum edukasi rata-rata kemampuannya yaitu 13.33 ,dengan standar deviasi 7.020, sedangkan kemampuan kader kesehatan dalam deteksi dini tanda bahaya kehamilan dan nifas setelah edukasi rata-rata kemampuannya yaitu 21.25 ,dengan standar deviasi 11.539. Terdapat perbedaan rata-rata kemampuan deteksi dini sebelum dan sesudah edukasi kader kesehatan yaitu 7.92.

\begin{tabular}{|c|c|c|}
\hline Pekerjaan & $\begin{array}{c}\text { Frekuensi } \\
(\mathbf{n})\end{array}$ & Persentase (\%) \\
\hline Bekerja & 1 & 4,2 \\
\hline Tidak bekerja & 23 & 95,8 \\
\hline TOTAL & 24 & 100 \\
\hline Berdasarkan table 3, diketahui bahwa
\end{tabular}

\section{Analisis Bivariat}

Sebelum melakukan uji statistic mengenai perbedaan rata-rata pengetahuan dan kemampuan deteksi dini sebelum dan sesudah, dilakukan terlebih dahulu uji normalitas data dengan uji Liliefors. Hasil uji normalitas didapatkan data berdistribusi tidak normal, sehingga uji statistic menggunakan uji Wilxocon.

Tabel 6. Analisis Wilxocon : Hubungan Edukasi Kader Kesehatan dengan Pengetahuan Tentang Tanda Bahaya Kehamilan dan Nifas

\section{d. Rata-rata Pengetahuan}

Tabel 4. Rata-rata Pengetahuan Kader Kesehatan Tentang Tanda Bahaya Kehamilan dan Nifas Sebelum dan Sesudah Edukasi

\begin{tabular}{|c|l|c|c|c|c|}
\hline \multirow{2}{*}{ No } & \multirow{2}{*}{ Edukasi } & \multicolumn{3}{|c|}{$\begin{array}{c}\text { Pengetahuan Tanda Bahaya } \\
\text { Kehamilan dan Nifas }\end{array}$} & \multirow{2}{*}{$\begin{array}{c}P- \\
\text { value }\end{array}$} \\
\cline { 3 - 5 } & & $\mathrm{N}$ & $\dot{\mathrm{x}}$ (Mean) & SD & \\
\hline 1 & $\begin{array}{l}\text { Sebelum } \\
\text { Edukasi }\end{array}$ & 24 & 15.58 & 3.078 & \\
& $\begin{array}{l}\text { Setelah } \\
\text { Edukasi }\end{array}$ & 24 & 17.21 & 3.799 & 0,081 \\
\hline
\end{tabular}

Berdasarkan tabel 4, pengetahuan kader kesehatan sebelum edukasi rata-rata pengetahuannya yaitu 15.58 ,dengan standar deviasi 3.078, sedangkan pengetahuan kader kesehatan setelah edukasi rata-rata pengetahuannya yaitu 17.21 ,dengan standar deviasi 3.799. Terdapat perbedaan rata-rata pengetahuan sebelum dan sesudah edukasi kader kesehatan yaitu 1.625 .

\begin{tabular}{|l|l|c|c|c|}
\hline \multirow{2}{*}{ No } & \multirow{2}{*}{ Edukasi } & \multicolumn{3}{|c|}{$\begin{array}{c}\text { Pengetahuan Tanda Bahaya } \\
\text { Kehamilan dan Nifas }\end{array}$} \\
\cline { 3 - 5 } & & $\mathrm{N}$ & $\dot{\mathrm{x}}$ ( Mean) & SD \\
\hline 1 & Sebelum Edukasi & 24 & 15.58 & 3.078 \\
2 & Setelah Edukasi & 24 & 17.21 & 3.799 \\
\hline
\end{tabular}

Berdasarkan tabel 6, perbedaan rata-rata pengetahuan kader kesehatan sebelum dan sesudah edukasi dengan nilai $\mathrm{P}>0,05(0,081)$. Dapat disimpulkan bahwa tidak terdapat perbedaan yang bermakna pengetahuan sebelum dan sesudah edukasi kader kesehatan.

Tabel 7. Analisis Wilxocon: Hubungan Edukasi Kader Kesehatan dengan Kemampuan Deteksi Dini Tentang Tanda Bahaya Kehamilan dan Nifas 


\begin{tabular}{|l|l|c|c|c|c|}
\hline \multirow{2}{*}{ No } & \multirow{2}{*}{ Edukasi } & \multicolumn{3}{|c|}{$\begin{array}{c}\text { Kemampuan Deteksi Dini } \\
\text { Tanda Bahaya Kehamilan } \\
\text { dan Nifas }\end{array}$} & \multirow{2}{*}{$\begin{array}{c}P- \\
\text { value }\end{array}$} \\
\cline { 3 - 5 } & & $\mathrm{N}$ & $\dot{\mathrm{x}}($ Mean $)$ & \multicolumn{1}{c|}{ SD } & \\
\hline 1 & Sebelum & 24 & 13.33 & 7.020 & \\
& Edukasi & 24 & 21.25 & 11.539 & 0,014 \\
2 & Setelah Edukasi & & & & \\
\hline
\end{tabular}

Berdasarkan table 7 , perbedaan rata-rata kemampuan deteksi dini kader kesehatan sebelum dan sesudah edukasi, dengan nilai $\mathrm{P}<0,05(0,014)$. Dapat disimpulkan bahwa terdapat perbedaan yang bermakna kemampuan deteksi dini sebelum dan sesudah edukasi kader kesehatan

\section{PEMBAHASAN}

\section{Efektifitas Edukasi Kader Kesehatan Terhadap Pengetahuan Tentang Tanda Bahaya Pada Kehamilan dan Nifas.}

Berdasarkan hasil analisis univariabel dan bivariabel, menunjukkan bahwa pengetahuan kader kesehatan sebelum edukasi rata-rata pengetahuannya yaitu 15.58 ,dengan standar deviasi 3.078, sedangkan pengetahuan kader kesehatan setelah edukasi rata-rata pengetahuannya yaitu 17.21 ,dengan standar deviasi 3.799. Terdapat perbedaan rata-rata pengetahuan sebelum dan sesudah edukasi kader kesehatan yaitu 1.625 ( adanya peningkatan rata-rata), dengan nilai $\mathrm{P}>$ 0,05 ( 0,081). Dapat disimpulkan bahwa tidak terdapat perbedaan yang bermakna pengetahuan sebelum dan sesudah edukasi kader kesehatan.

Berbagai studi analisis menunjukkan ada perbedaan sebelum dan sesduah edukasi. Hal ini sejalan dengan hasil Pengabdian masyarakat Kurniati Puji Lestari et all. ${ }^{(4)}$ dengan judul " penyegaran kader tentang tanda - tanda kehamilan, cara mengatasi masalah kehamilan dan persiapan persalinan di lingkungan wilayah kerja puskesmas srondol kota semarang " hasil yang diperoleh dari kegiatan pengabdian kepada masyarakat ini adalah meningkatnya pengetahuan para kader tentang kehamilan dan persiapan persalinan. hal ini dapat dilihat dari meningkatnya hasil penilaian pre test dan post test. hasil dari pretest sebanyak $40 \%$ peserta mempunyai nilai 60 - 80, 60\% medapatkan nilai 20 50 sedangkan pada posttest sebanyak $80 \%$ peserta mempunyai nilai 80 - 90, 20\% mendapatkan nilai 60 70 .

Demikian juga dengan penelitian Fitria Hayu Palupi et all. (9) dengan judul " Tingkat pengetahuan kader kesehatan tentang tanda bahaya kehamilan di desa bolon kecamatan colomadu", dengan hasil penelitian dapat disimpulkan bahwa tingkat pengetahuan kader kesehatan tentang tanda bahaya kehamilan di Desa Bolon, tergolong cukup sebanyak 20 responden $(66,7 \%)$.
Hasil rata-rata pengetahuan kader sebelum dan sesudah edukasi tergolong sudah cukup pengetahuannya dan menunjukkan adanya peningkatan. Hal ini kemungkinan dapat terjadi dikarenakan para kader sudah pernah terpapar informasi dari petugas kesehatan Puskesmas atau Dinas Kesehatan atau pada saat mengikuti kegiatan kelas ibu hamil. Sesuai dengan teori yang mengatakan bahwa Semakin banyak informasi yang diperoleh seseorang, maka semakin banyak pengetahuan yang akan didapatkan. Seseorang yang mempunyai sumber informasi lebih banyak akan mempunyai pengetahuan yang lebih luas. Informasi yang diperoleh dari beberapa sumber akan mengetahui tingkat pengetahuan seseorang. Bila seseorang banyak memperoleh informasi maka ia cenderung memiliki pengetahuan yang lebih luas. ${ }^{(7)}$

Begitu pula dengan pengalaman yang sudah diperoleh dapat memperluas pengetahuan seseorang. Pengalaman dapat diperoleh dari pengalaman sendiri maupun orang lain. Bertambahnya umur seseorang, maka akan bertambah pula pengetahuannya dari yang tadinya tidak tahu menjadi tahu. Semakin banyak usia seseorang maka semakin bijaksana dan banyak pengalaman/ hal yang telah dijumpai dan dikerjakan untuk memiliki pengetahuan. Dengan pengetahuan tersebut dapat mengembangkan kemampuan mengambil keputusan yang merupakan manifestasi dari keterpaduan menalar secara ilmiah dan etik yang bertolak dari masalah nyata. ${ }^{(7)}$ Sebesar $58.3 \%$ kader berada pada rentang usia reproduktif yaitu 25-35 tahun.

Dari hasil penelitian peningkatan rata-rata pengetahuan kader sebelum dan sesudah edukasi hanya 1.625. Peningkatan yang terjadi tidak begitu banyak, dan dari hasil analisis bivaribel menunjukkan tidak ada perbedaan yang bermakna. Hal ini kemungkinan dapat terjadi karena pendidikan kader $62.5 \%$ adalah SD dan bahkan ada yang tidak tamat SD sebesar $8.3 \%$. Bahkan masih ditemukannya kader yang belum lancar atau bahkan tidak bisa baca tulis, sehingga kader tersebut tidak termasuk kriteria inklusi dan dikeluarkan sebagai responden. Tingkat pendidikan yang tinggi akan sangat berpengaruh bagi seseorang. Makin tinggi pendidikan, makin mudah seseorang menerima pengetahuan. ${ }^{(7)}$

Tingkat pendidikan juga mempengaruhi persepsi seseorang untuk lebih menerima ide-ide dan teknologi baru. Pendidikan juga merupakan salah satu faktor yang mempengaruhi persepsi seseorang. Karena dapat membuat seseorang untuk lebih mudah mengambil keputusan dan bertindakang untuk dapat menerima segala macam bentuk perubahan.

Begitu pula dengan pekerjaan kader yang 95.8 $\%$ adalah tidak bekerja. Pekerjaan mempengaruhi tingkat pengetahuan. Pekerjaan yang memungkinkan seseorang mempunyai waktu luang lebih banyak dan digunakan mengikuti kegiatan-kegiatan yang ada di lingkungan sekitar atau pendidikan non formal akan dapat meningkatkan pengetahuan. 


\section{Efektifitas Edukasi Kader Kesehatan Terhadap Kemampuan Deteksi Dini Tentang Tanda Bahaya Pada Kehamilan dan Nifas}

Berdasarkan hasil analisis univariabel dan bivariabel, menunjukkan bahwa kemampuan deteksi dini kader kesehatan sebelum edukasi rata-rata kemampuannya yaitu 13.33 ,dengan standar deviasi 7.020, sedangkan kemampuan kader kesehatan dalam deteksi dini tanda bahaya kehamilan dan nifas setelah edukasi rata-rata kemampuannya yaitu 21.25 ,dengan standar deviasi 11.539. Terdapat perbedaan rata-rata kemampuan deteksi dini sebelum dan sesudah edukasi kader kesehatan yaitu 7.92, dengan nilai $\mathrm{P}<0,05$ $(0,014)$. Dapat disimpulkan bahwa terdapat perbedaan yang bermakna kemampuan deteksi dini sebelum dan sesudah edukasi kader kesehatan.

Berbagai studi analisis menunjukkan ada perbedaan sebelum dan sesudah edukasi. Hal ini sejalan dengan hasil Muhammad Agus Mikrajab dan Tety Rachmawaty. ${ }^{(6)}$ dengan judul "Peran kader kesehatan dalam program perencanaan Persalinan dan pencegahan komplikasi pada ibu hamil di posyandu di kota mojokerto, provinsi jawa timur (the role of health cadres in applying childbirth planning and Complications prevention program for pregnant women at integrated Health services post in mojokerto city, east java province) Tahun 2011, menunjukkan bahwa peran kader kesehatan yang telah dilaksanakan adalah dalam memotivasi pemeriksaan kehamilan telah mencapai $100 \%$; namun tindakan merujuk ke puskesmas baru mencapai $62,7 \%$. Sehingga peran kader kesehatan intensitasnya masih perlu ditingkatkan.

Upaya pendeteksian dini tanda bahaya pada kehamilan, dan nifas dapat dilakukan oleh tenaga kesehatan maupun oleh masyarakat. Kader kesehatan merupakan sumber daya yang dapat membantu tenaga kesehatan dalam mendeteksi dini terhadap tanda bahaya kehamilan dan nifas. Tugas kader kesehatan dalam deteksi dini ibu hamil dan nifas dengan faktor risiko adalah mengidentifikasi ibu hamil dan nifas, memberikan penyuluhan selama kehamilan dan nifas, melakukan rujukan ke fasilitas pelayanan kesehatan (puskesmas, rumah sakit) sesuai dengan risiko yang ditemukan. ${ }^{(10)}$

Dari hasil penelitian menunjukkan rata-rata kemampuan deteksi dini kader tentang tanda bahaya kehamilan dan nifas masih rendah. Pada saat pre test hanya 13.33 dan sesudah 21.25. Peningkatan rata-rata kemampuan kader sebelum dan sesudah edukasi cukup tinggi yaitu sebesar 7.92. Peningkatan rata-rata yang terjadi cukup tinggi, dan dari hasil analisis bivaribel menunjukkan ada perbedaan yang bermakna.

Hal ini kemungkinan dapat terjadi karena pada awal atau pada saat pre test masih kurangnya pengalaman kader dalam melakukan deteksi dini tanda bahaya kehamilan dan nifas dan kurangnya informasi bagaimana melakukan deteksi dini dan kurang mengetahui cara komunikasi dalam mengkaji. Kemudahan untuk memperoleh suatu informasi dapat mempercepat seseorang memperoleh pengetahuan baru. Semakin banyak informasi yang diperoleh seseorang, maka semakin banyak pengetahuan yang akan didapatkan. Seseorang yang mempunyai sumber informasi lebih banyak akan mempunyai pengetahuan yang lebih luas. Informasi yang diperoleh dari beberapa sumber akan mengetahui tingkat pengetahuan seseorang. Bila seseorang banyak memperoleh informasi maka ia cenderung memiliki pengetahuan yang lebih luas. Begitu pula dengan pengalaman yang sudah diperoleh dapat memperluas pengetahuan seseorang. ${ }^{(7)}$

Setelah dilakukan edukasi terjadi peningkatan kemampuan deteksi dini kader tentang tanda bahaya kehamilan dan nifas. Hal ini kemungkinan dapat terjadi karena setelah dilberikan edukasi kader menjadi memiliki pengetahuan tentang bagaimana mengkaji tanda bahaya kehamilan dan nifas.

Meskipun terjadi peningkatan yang cukup tinggi dari rata-rata nilai pre test dan post test, namun peningkatan masih tergolong cukup. Tingkatan pengetahuan yang mungkin terjadi pada peningkatan rata-rata post test kemampuan deteksi dini tanda bahaya kehamilan dan nifas adalah 1) Memahami (Comprehension), 2) Aplikasi (Application), 3) Analisis (Analysis), 4) Sintesis (Synthesis), 5) Evaluasi (Evalution). ${ }^{(8)}$

\section{KESIMPULAN}

Karakteristik responden sebagian besar pada rentang usia 25-34 tahun, pendidikan SD, dan pekerjaan tidak bekerja. Rata-rata pengetahuan tanda bahaya kehamilan, dan nifas sebelum diberikan edukasi kader kesehatan sebesar 15.58. Rata-rata pengetahuan tanda bahaya kehamilan, dan nifas sesudah diberikan edukasi kader kesehatan sebesar 17.21 Rata-rata pengetahuan tanda bahaya kehamilan, dan nifas, sebelum diberikan edukasi kader kesehatan dan sesudah edukasi kader kesehatan tidak terdapat perbedaan yang bermakna pengetahuan sebelum dan sesudah edukasi kader kesehatan. Rata-rata kemampuan deteksi dini tanda bahaya kehamilan, dan nifas sebelum diberikan edukasi kader kesehatan sebesar 13.33. Rata-rata kemampuan deteksi dini tanda bahaya kehamilan, dan nifas sesudah diberikan edukasi kader kesehatan sebesar 21.25. Rata-rata kemampuan deteksi dini tanda bahaya kehamilan, dan nifas, sebelum diberikan edukasi kader kesehatan dan sesudah edukasi kader kesehatan terdapat perbedaan yang bermakna kemampuan deteksi dini sebelum dan sesudah edukasi kader kesehatan.

Saran bagi fasilitas kesehatan dan tenaga kesehat agar lebih meningkatkan serta mengembangkan program dan kebijakan yang dapat meningkatkan pengetahuan dan kemampuan kader dalam mendeteksi dini tanda bahaya kehamilan dan nifas yang terjadi di masyarakat, serta lebih 
meningkatkan kriteria kader kesehatan sehingga tidak ada lagi kader kesehatan yang terpilih masih tidak bisa membaca menulis, dan agar lebih meningkatkan peran sertanya dalam memberikan informasi dan menambah kemampuan kader dalam mendeteksi dini tanda bahaya kehamilan dan nifas, selain dalam kegiatan kelas ibu hamil.

\section{DAFTAR PUSTAKA}

1. Depkes RI (2001) Buku Pedoman Pengenalan Tanda Bahaya pada Kehamilan, Persalinan, dan Nifas. Jakarta: Depkes.RI.

2. Dinas Kesehatan Kota Cirebon. 2014 Profil Kesehatan Indonesia Kota Cirebon Tahun 2014.

3. Kemenkes, RI 2013. Profil Kesehatan Indonesia.Jakarta : Kemenkes RI.

4. Lestari, Kurniati Puji, et all (2016) 'Penyegaran kader tentang tanda - tanda kehamilan, cara mengatasi masalah kehamilan dan persiapan persalinan di lingkungan wilayah kerja puskesmas srondol kota semarang'.

5. Manuaba, I.B.G,. Chandranita, Fajar (2007) Pengantar Kuliah Obstetri. Jakarta: EGC.

6. Mikrajab, M. A. dan Rahmawati, T. (2011) 'Peran kader kesehatan dalam program perencanaan Persalinan dan pencegahan komplikasi pada ibu hamil di posyandu di kota mojokerto, provinsi jawa timur'.

7. Mubarak, W. I. (2011) Promosi Kesehatan Untuk Kebidanan. Salemba Medika.

8. Notoatmodjo, S. (2007) Metodologi Penelitian Kesehatan. Jakarta: Rineka Cipta.

9. Palupi, Fitria Hayu et all (2012) 'Tingkat pengetahuan kader kesehatan tentang tanda bahaya kehamilan di desa bolon kecamatan colomadu'.

10. Sugiarti, dan dkk (2012) 'Upaya Pemberdayaan Ibu Hamil Untuk Deteksi Dini Risiko Tinggi Kehamilan Trimester I', The Indonesian Journal of Public Health, 9(1), pp. 27-36. 